\title{
Phenolic profile, antioxidant and antibacterial properties of Juglans regia L. (walnut) leaves from the Northeast of Portugal
}

\author{
Vanessa Vieira $^{\mathrm{a}, \mathrm{b}, \mathrm{c}}$, Carla Pereira ${ }^{\mathrm{a}}$, Tânia C.S.P. Pires ${ }^{\mathrm{a}}$, Ricardo C. Calhelha ${ }^{\mathrm{a}}$, Maria José Alves $^{\mathrm{a}}$, \\ Olga Ferreira $^{\mathrm{a}, \mathrm{c}}$, Lillian Barros ${ }^{\mathrm{a}, *}$, Isabel C.F.R. Ferreira ${ }^{\mathrm{a}, *}$ \\ ${ }^{a}$ Centro de Investigação de Montanha (CIMO), Instituto Politécnico de Bragança, Campus de Santa Apolónia, 5300-253, Bragança, Portugal \\ ${ }^{\mathrm{b}}$ CICECO - Aveiro Institute of Materials, Complexo de Laboratórios Tecnológicos, Aveiro University, Campus Universitário de Santiago, 3810-193, Aveiro, Aveiro, Portugal \\ ${ }^{\mathrm{c}}$ Laboratory of Separation and Reaction Engineering - Laboratory of Catalysis and Materials (LSRE-LCM), Instituto Politécnico de Bragança, Campus de Santa Apolónia, \\ 5300-253, Bragança, Portugal
}

\section{A R T I C L E I N F O}

\section{Keywords:}

Juglans regia L. leaves

Phenolic compounds

Antioxidants

Anti-inflammatory

Antibacterial

Cytotoxicity

\begin{abstract}
A B S T R A C T
Juglans regia L. (walnut tree) is a recognized source of bioactive compounds with potential health benefits. In this work, hydroethanolic extracts of $J$. regia leaves were obtained by heat assisted extraction from different Portuguese samples in two phenological stages (green and yellow leaves) aiming to assess the impact of seasonal variations. The samples were compared regarding their phenolic composition and bioactivity. Seventeen phenolic compounds were identified by liquid chromatography combined with a diode array detector and electrospray ionization mass spectrometer (LC-DAD-ESI/MS ${ }^{\mathrm{n}}$ ): six phenolic acids, ten flavonoids and one tetralone derivative. The green leaves extracts presented a higher amount of total phenolic compounds $(29.70 \pm 0.03 \mathrm{mg} / \mathrm{g}$ extract$)$ compared with the yellow leaves $(23.26 \pm 0.06 \mathrm{mg} / \mathrm{g}$ extract $)$. In particular, yellow samples were richer in flavonoids $(17.4 \pm 0.2 \mathrm{mg} / \mathrm{g}$ extract; mainly quercetin-3-O-glucoside: $3.64 \pm 0.01 \mathrm{mg} / \mathrm{g}$ extract), while the green ones presented higher phenolic acids content $(16.7 \pm 0.2 \mathrm{mg} / \mathrm{g}$ extract; mainly trans 3-p-coumaroylquinic acid: $6.9 \pm 0.5 \mathrm{mg} / \mathrm{g}$ extract). Green leaves extract also presented higher antioxidant potential, achieving $\mathrm{IC}_{50}$ values around $32 \pm 2 \mu \mathrm{g} / \mathrm{mL}$ and $26.8 \pm 0.2 \mu \mathrm{g} / \mathrm{mL}$ for the oxidative haemolysis inhibition and the thiobarbituric acid reactive substances assays, respectively. Furthermore, only green leaves samples showed anti-inflammatory potential. The cytotoxic evaluations revealed similar antiproliferative action of both extracts against the tumor cell lines tested. Also, an analogous anti-bacterial potential of the extracts was observed, with preferential action against Gram-positive clinical isolated bacteria, with lower minimum inhibitory concentration (MIC) values for Enterococcus faecalis and Listeria monocytogenes (MIC $=2.5 \mathrm{mg} / \mathrm{mL}$ ). Therefore, the present study suggests the use of walnut leaves as a source of active ingredients without hepatotoxic effects to be used in different applications in the food or pharmaceutical areas.
\end{abstract}

\section{Introduction}

Medicinal plants have been used for centuries by different civilizations as therapeutic agents due to their preventive and curative properties (Tasneem et al., 2019). Juglans regia L. is spread across the globe, being walnut leaves widely used by the folk medicine as antiseptic, antiinflammatory, antidiabetic, anti-helminthic and antidiarrheic agents. Furthermore, they are also traditionally used for the treatment of hyperhidrosis, ulcers and dandruff (Carvalho et al., 2010a; Cosmulescu et al., 2014). Moreover, J. regia leaves extract is an inventoried ingredient for cosmetic products, with reported astringent, soothing, cleansing, abrasive, bulking, skin conditioning, and masking functions
(European Commission, 2006).

Many studies reported the bioactivity of walnut leaves by several in vitro (cell cultures) and in vivo (rats/mice) assays regarding their antidiabetic (Asgary et al., 2008; Hosseini et al., 2014; Javidanpour et al., 2012; Mohammadi et al., 2012; Mollica et al., 2017; Pitschmann et al., 2014; Teimori et al., 2009), anti-inflammatory (Erdemoglu et al., 2003; Hosseinzadeh et al., 2011), anti-proliferative (Salimi et al., 2014; Santos et al., 2013), anti-septic/biofilm/bacterial (Dolatabadi et al., 2018; Pereira et al., 2007), hepatoprotective (Eidi et al., 2013), sedative and analgesic (Erdemoglu et al., 2003; Gîrzu et al., 1998; Hosseinzadeh et al., 2011), vasorelaxant (Perusquía et al., 1995), and neuroprotective (Orhan et al., 2011) properties. The study performed by Wang et al.

\footnotetext{
* Corresponding authors.

E-mail addresses: lillian@ipb.pt (L. Barros), iferreira@ipb.pt (I.C.F.R. Ferreira).
} 
(2015) evaluated the anti-hyperuricemia potential of $J$. regia leaves by determining the xanthine oxidase inhibitory activity. Moreover, the extensive evidences on the anti-diabetic activity of walnut leaves encouraged Abdoli et al. (2017) to carry out a human trial using walnut leaves-based preparations in Type II diabetic patients, obtaining positive results for the reduction of the glycemic index and HbA1c (glycated hemoglobin) values.

The secondary metabolites of $J$. regia leaves have been related to its therapeutic effects, such compounds including phenolic acids, flavonoids, organic acids, tocopherols, triterpenic acids, terpenes, terpenoids, tetralone derivatives, megastigmane derivatives, hydroxy-1,4naphthoquinone (juglone) derivatives, among others (Cosmulescu et al., 2011; Forino et al., 2016; Panth et al., 2016; Rather et al., 2012; Salimi et al., 2014; Santos et al., 2013; Schwindl and Kraus, 2017). Phenolic compounds are the main fraction found in the plant material. They are natural occurring antioxidants, largely recognized because of their health benefits due to their radical scavenging activity, reducing oxidative stress, which is the main cause of several disorders. In fact, these exogenous antioxidant source play an important role for the oxidative stress balance, providing additional antioxidant potential for living organisms, since there is an insufficient action of our endogenous antioxidant system (Carocho and Ferreira, 2013). In this context, the inclusion of walnut leaves preparations (food and supplements) in our diet could act as a preventive medicine with several health benefits (Pires et al., 2018).

The use of $J$. regia leaves goes back from centuries, and in Portugal, especially in the northeast region (Bragança) they are traditionally used as an external antiseptic, anti-inflammatory and antidiabetic agent (Carvalho et al., 2010a). In this context, the study of walnut leaves from this region, characterizing their main constituents and potential bioactivities, will contribute to support their traditional medicinal uses with scientific evidences, valorizing this species and its origin. In this work, Portuguese walnut leaves in two phenological stages (green and yellow leaves) were evaluated aiming to assess the impact of seasonal variations on the phenolic compounds composition and the bioactive potential of the extracts obtained. The seasonal variation of the phytochemical profile of this plant material has been previously established by Cosmulescu et al. (2014) using Romanian samples. Along that study, samples were collected during each fortnight from 1 st of June to 15th of August 2012 and were only compared in terms of their phytochemical abundancy (ellagic acid, rutin, myricetin and juglone).

In order to achieve the aims proposed in this study, a hydroethanolic extract was evaluated regarding its antioxidant, cytotoxic and antibacterial activities, and the phenolic profile was obtained by LCDAD-ESI/MS ${ }^{\text {. }}$

\section{Material and methods}

\subsection{Plant material and extract preparation}

Juglans regia L. (walnut) leaves were collected in Bragança, Northeast of Portugal, in May (green leaves) and November (yellow leaves) of 2018. The samples were dried until constant weight in an incubator at $35^{\circ} \mathrm{C}$. Then, the plant material was ground to approximately 40 mesh, and the homogeneous samples were stored in a desiccator protected from light.

The hydroethanolic extract was obtained by heat assisted extraction, using the previous optimized conditions for the extraction of phenolic compounds reported by the authors (Vieira et al., 2017): aqueous ethanolic solution $(50.4 \%, \mathrm{v} / \mathrm{v} ; 30 \mathrm{~g} / \mathrm{mL})$ at $61.3{ }^{\circ} \mathrm{C}$ for 116 min. After filtration (Whatman no. 4 filter), the solvent was first evaporated at $40^{\circ} \mathrm{C}$, under reduced pressure, in a rotary evaporator (Büchi R-210, Flawil, Switzerland) and the residual solvent was removed in a freeze drier (Telstar Cryodos-80, Terrassa, Barcelona).

\subsection{Phenolic compounds characterization}

The dry extracts were re-suspended at a concentration of $10 \mathrm{mg} / \mathrm{mL}$ using aqueous ethanol $(20 \%, \mathrm{v} / \mathrm{v})$ and filtered $(0.2 \mu \mathrm{m}$ disposable LC filter disk, $30 \mathrm{~mm}$, nylon). Afterwards, the phenolic profile of walnut leaves was found by liquid chromatography with diode-array detector (280, 330, and $370 \mathrm{~nm}$ wavelengths) coupled to an electrospray ionization mass spectrometry operating in negative mode (Dionex Ultimate 3000 UPLC and Linear Ion Trap LTQ XL, Thermo Scientific, San Jose, CA, USA), as previously described by the authors (Bessada et al., 2016). The phenolic compounds were identified according to their chromatographic characteristics by comparison to those obtained with standard compounds and with literature. Calibration curves of appropriate standards were obtained in the range $200-5 \mu \mathrm{g} / \mathrm{mL}$, for the quantitative analysis. The results were expressed in $\mathrm{mg}$ per $\mathrm{g}$ of extract $(\mathrm{mg} / \mathrm{g})$.

\subsection{In vitro antioxidant assays}

The lipid peroxidation inhibition in porcine (Sus scrofa) brain homogenates was evaluated through the thiobarbituric acid reactive substances (TBARS) assay. The ethanolic extracts were prepared at a concentration of $10 \mathrm{mg} / \mathrm{mL}$ in distilled water and further successive dilutions were performed to obtain the working concentrations ranging from 400 to $6.25 \mu \mathrm{g} / \mathrm{mL}$. The decrease of the TBARS production was performed by measuring the color intensity of the malondialdehydethiobarbituric acid (MDA-TBA) at $532 \mathrm{~nm}$. The methodology followed was previously reported by Barreira et al. (2013) with slight modifications. Briefly, dissected porcine brain was homogenized with Tris $-\mathrm{HCl}$ buffer $(20 \mathrm{mM}, \mathrm{pH} 7.4)$ at a ratio of 1:2 (w/v). The homogenate was centrifuged ( $3000 \mathrm{rpm}$ for $10 \mathrm{~min})$ and an aliquot $(100 \mu \mathrm{L})$ of the supernatant was incubated with the stock solutions of extract $(200 \mu \mathrm{L}), \mathrm{FeSO}_{4}(10 \mathrm{mM} ; 100 \mu \mathrm{L})$ and ascorbic acid $(0.1 \mathrm{mM} ; 100 \mu \mathrm{L})$ at $37^{\circ} \mathrm{C}$ for $60 \mathrm{~min}$. Then, the reaction was stopped by adding trichloroacetic acid $(28 \%, \mathrm{w} / \mathrm{v}, 500 \mu \mathrm{L})$, thiobarbituric acid $(2 \%, \mathrm{w} / \mathrm{v}$, $380 \mu \mathrm{L}$ ), and heating the mixture at $80^{\circ} \mathrm{C}$ for $20 \mathrm{~min}$. After that, the mixtures were centrifuged ( $3000 \mathrm{rmp}$ ) for $10 \mathrm{~min}$ and the absorbances of the supernatants were measured. The inhibition ratio (\%) was calculated using the following formula: $[(\mathrm{A}-\mathrm{B}) / \mathrm{A}] \times 100 \%$, being $\mathrm{A}$ and $\mathrm{B}$ the absorbance of the control and the sample solution, respectively. The $\mathrm{EC}_{50}$ value defines the concentration providing $50 \%$ of antioxidant activity, and was calculated by interpolation from the graph of TBARS formation inhibition percentage against sample concentration.

The anti-haemolytic activity of walnut leaves samples was evaluated by the oxidative haemolysis inhibition assay (OxHLIA). The adopted methodology was previously described by Takebayashi et al. (2012); however, slight modifications were implemented. Erythrocytes were obtained from sheep blood collection. Healthy animals were selected for the purpose and the full blood was centrifuged at $1000 \mathrm{~g}$ at $10^{\circ} \mathrm{C}$ for $5 \mathrm{~min}$. Then, plasma and buffy coats were discarded and erythrocytes were once washed with $\mathrm{NaCl}(150 \mathrm{nM})$ and three times with phosphate buffer solution (PBS, pH 7.4) (Evans et al., 2013), being the erythrocyte fraction resuspended in PBS $(2.8 \%, \mathrm{v} / \mathrm{v})$. The extract was dissolved in PBS (pH 7.4) to obtain a stock solution of $10 \mathrm{mg} / \mathrm{mL}$, and successive solutions were prepared, ranging from 400 to $6.25 \mu \mathrm{g} / \mathrm{mL}$. About $400 \mu \mathrm{L}$ of each solution was transferred for a 48 well plate (duplicates). Water and PBS (pH 7.4) were used as controls of haemolysis (plasmolytic and isotonic media, respectively) and Trolox as positive control. Then, the suspension of erythrocytes $(200 \mu \mathrm{L})$ was mixed with the previous solutions/controls and the 48-well plate was incubated for $10 \mathrm{~min}$ at $37.5^{\circ} \mathrm{C}$ with agitation. After that, a solution of $2,2^{\prime}$-azobis(2methylpropionamidine) dihydrochloride (AAPH, $160 \mathrm{mM}$ in PBS, $200 \mu \mathrm{L}$ ) was added and the absorbance of the mixtures was measured at $690 \mathrm{~nm}$ (BioTek ELx800). The microplate was incubated under the same conditions and absorbances were measured every 10 min during approximately $400 \mathrm{~min}$. The percentage of the erythrocyte population that remained intact $(P)$ was calculated using the following equation: 
$P(\%)=\left(\mathrm{S}_{\mathrm{t}}-\mathrm{CH}_{0} / \mathrm{S}_{0}-\mathrm{CH}_{0}\right) \times 100$

where $S_{t}$ and $S_{0}$ correspond to the absorbance of the sample at time $t$ and $0 \mathrm{~min}$, respectively, and $\mathrm{CH}_{0}$ is the absorbance of the complete haemolysis at $0 \mathrm{~min}$. The results were, then, expressed as delayed time of haemolysis $(\Delta t)$, which was calculated according to the following equation:

$\Delta t(\min )=\mathrm{Ht}_{50}($ sample $)-\mathrm{Ht}_{50}$ (control)

where $\mathrm{Ht}_{50}$ is the haemolytic time (minutes) obtained by graphical representation of the haemolysis curve of each sample concentration. Then, the $\Delta t$ values were correlated to the antioxidant sample concentrations promoting the desirable $\Delta t$ haemolysis delay (Takebayashi et al., 2012). The results were expressed as $\mathrm{IC}_{50}$ values $(\mu \mathrm{g} / \mathrm{mL})$ at $60 \mathrm{~min}$, meaning the extract concentration required to keep $50 \%$ of the erythrocytes intact for $60 \mathrm{~min}$.

\subsection{Anti-inflammatory activity}

The walnut leaves extracts were re-dissolved in water at a concentration of $8 \mathrm{mg} / \mathrm{mL}$ and then diluted in the range of 400 to $6.25 \mu \mathrm{g}$ / $\mathrm{mL}$ using supplemented DMEM (10\% heat-inactivated fetal bovine serum, $2 \mathrm{mM}$ glutamine, 10\% MEM non-essential amino acids solution, $100 \mathrm{U} / \mathrm{mL}$ penicillin and $100 \mu \mathrm{g} / \mathrm{mL}$ streptomycin). A mouse macrophage-like cell line RAW264.7 was used in this study and maintained at $37^{\circ} \mathrm{C}$ under $5 \%$ of $\mathrm{CO}_{2}$. Briefly, a suspension of cells $\left(5 \times 10^{5}\right.$ cells $\left./ \mathrm{mL}\right)$ was allowed to sediment on the 96-well plate $\left(1.5 \times 10^{5}\right.$ cells/well $)$ overnight. Then, cells were treated with the different concentrations of extract for $60 \mathrm{~min}$. Thereafter, the cells were stimulated with LPS ( $1 \mu \mathrm{m} \mathrm{g} / \mathrm{mL}$, in supplemented DMEM) during $18 \mathrm{~h}$. Besides the GRS, the kit contains sulfanilamide, N-(1-naphthyl)ethylenediamine dihydrochloride (NED) and nitrite solutions. The cell culture supernatant $(100 \mathrm{~L})$ was transferred to the plate in duplicate and mixed with sulfanilamide and NED solutions, 5 and 10 min each, at room temperature. The nitrite produced was determined by measuring the optical density at $515 \mathrm{~nm}$, using the EL $x 800$ microplate reader (Bio-Tek Instruments, Inc; Winooski, VT, USA) following a methodology previously reported (Correa et al. 2015). The results were expressed in $\mathrm{EC}_{50}$ values (sample concentration providing $50 \%$ of inhibition of NO production) and dexamethasone was used as a positive control, while in negative controls no LPS was added.

\subsection{Cytotoxic assays}

The extracts were re-dissolved in water at $8 \mathrm{mg} / \mathrm{mL}$ concentration and further diluted in the range 400 to $6.25 \mu \mathrm{g} / \mathrm{mL}$. The four human tumor cell lines assessed (MCF-7, breast adenocarcinoma; NCI-H460, non-small cell lung cancer; HeLa, cervical carcinoma; and HepG2, hepatocellular carcinoma) were maintained as adherent cell cultures in RPMI-1640 medium containing heat-inactivated fetal bovine serum (FBS, 10\%), glutamine ( $2 \mathrm{mM})$, MEM non-essential amino acids solution $(10 \%)$, and antibiotics $(100 \mathrm{U} / \mathrm{mL}$ penicillin and $100 \mathrm{mg} / \mathrm{mL}$ streptomycin) at $37{ }^{\circ} \mathrm{C}$, in a humidified air incubator with $\mathrm{CO}_{2}(5 \%)$. For evaluation of the cytotoxicity in non-tumor cells, a cell culture designated as PLP2, was prepared from a freshly harvested porcine liver obtained from a local slaughterhouse, according to a procedure established by Abreu et al. (2011). The cell proliferation of each cell culture was monitored every two to three days using a phase contrast microscope and, before confluence was reached, the cells were subcultured in the supplemented RPMI-1640 medium mentioned above. Then, the cells were distributed in 96-well-plates $(190 \mu \mathrm{L})$ according to their appropriate density $\left(1.0 \times 10^{4}\right.$ cells/well for all cell cultures) and tested with the solutions of extracts $(10 \mu \mathrm{L})$ during $48 \mathrm{~h}$. Ellipticine was used as positive control. Hereinafter, the adherent cells were fixed by adding trichloroacetic acid (TCA, $10 \%, 100 \mu \mathrm{L}$ ) and incubation at $4{ }^{\circ} \mathrm{C}$ for
$60 \mathrm{~min}$. After the incubation period, the TCA was removed and plates were washed (distilled water, three times) and dried. The sulforhodamine B solution (SRB, $0.1 \%$ in $0.1 \%$ acetic acid, $100 \mu \mathrm{L}$ ) was then added and allowed to bound at room temperature for $30 \mathrm{~min}$. The excess of SRB was removed by washing the 96-well plates with acetic acid (1\%, three times) and allowed to dry. The bound SRB was solubilized by adding Tris buffer solution $(10 \mathrm{mM}, 200 \mu \mathrm{L})$ and the absorbances were measured at $540 \mathrm{~nm}$ using the microplate reader mentioned above. The results were expressed in $\mathrm{GI}_{50}$ values (concentration that inhibited $50 \%$ of the cell proliferation), being the negative control constituted by each suspension of cells (Barros et al., 2013).

\subsection{Antibacterial activity}

The antimicrobial potential of the walnut husks was assessed for bacterial strains obtained from patients hospitalized in different departments at the Northeastern local health unit (Bragança, Portugal) and Hospital Center of Trás-os-Montes and Alto Douro (Vila Real, Portugal). Five Gram-negative bacteria (Escherichia coli, isolated from urine; Proteus mirabilis, isolated from wound exudate; Klebsiella pneumoniae, isolated from urine; Pseudomonas aeruginosa, isolated from expectoration; and Morganella morganii, isolated from urine), three Grampositive bacteria (Enterococcus faecalis, isolated from urine; Listeria monocytogenes, isolated from cerebrospinal fluid; methicillin-resistant Staphylococcus aureus (MRSA), isolated from expectoration) were tested. All these microorganisms were incubated at $37^{\circ} \mathrm{C}$ in appropriate fresh medium for $24 \mathrm{~h}$ before analysis to maintain the exponential growth phase. The minimum inhibitory concentration (MIC) determinations on all bacteria were performed using a colorimetric assay described by Pires et al. (2018).

The extracts were dissolved in a mixture of dimethyl sulfoxide (DMSO) + Mueller-Hinton Broth (MHB; E. coli, P. mirabilis, K. pneumoniae, $P$. aeruginosa, M. morganii and MRSA)/ Tryptic Soy Broth (TSB, E. faecalis and $L$. monocytogenes $)(5+95 \%, \mathrm{v} / \mathrm{v})$ to give a final concentration of $100 \mathrm{mg} / \mathrm{mL}$ for the stock solution and successive dilutions were further carried out ranging from 20 to $1.25 \mathrm{mg} / \mathrm{mL}$. Then, $90 \mu \mathrm{L}$ of each concentration and $10 \mu \mathrm{L}$ of each inoculum (standardized at $1.5 \times 10^{8}$ Colony Forming Unit (CFU)/mL) were pipetted (duplicates) for a $96-$ well microplate. Three negative controls were prepared (1: MHB/ TSB; 2: extract; 3: medium + antibiotic + bacteria), whereas, the positive control was prepared with MHB/TSB and each inoculum. The Ampicillin and Imipenem antibiotics were used as negative control for all Gram-negative bacteria tested and Listeria monocytogenes, while Ampicillin and Vancomycin were selected for Enterococcus faecalis and MRSA. The microplates were covered and incubated at $37^{\circ} \mathrm{C}$ for $24 \mathrm{~h}$. The MIC of samples was detected following addition of $p$-iodonitrotetrazolium chloride (INT) $(0.2 \mathrm{mg} / \mathrm{mL}, 40 \mu \mathrm{L})$ and further incubation at $37^{\circ} \mathrm{C}$ for $30 \mathrm{~min}$. MIC was defined as the lowest concentration that inhibits the bacterial growth, determined visually by change of the coloration from yellow to pink (viable microorganism) as previously described by Kuete et al. (2011). To determine the minimum bactericidal concentration (MBC), $10 \mu \mathrm{L}$ of liquid from each well that showed no change in colour was inoculated on Blood agar solid medium (7\% sheep blood) and incubated at $37^{\circ} \mathrm{C}$ for $24 \mathrm{~h}$. The MBC was determined according to the lowest concentration that yielded no growth. Meanwhile, MBC was established as the lowest concentration required to kill bacteria.

\subsection{Statistical analysis}

Triplicates of green and yellow samples were assayed and three repetitions of each methodology were performed, being the results expressed as mean values and standard deviations (SD). The significant differences between the two samples were established by applying a Student's $t$-test, with $p=0.05$ (SPSS v. 23.0 program). 
Table 1

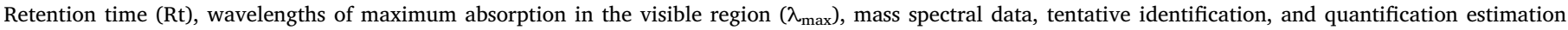
(mean $\pm \mathrm{SD}$ ) of the tentatively identified phenolic compounds in green and yellow leaves extracts of $J$. regia.

\begin{tabular}{|c|c|c|c|c|c|c|c|c|}
\hline Peak & Rt (min) & $\begin{array}{l}\lambda \max \\
(\mathrm{nm})\end{array}$ & $\begin{array}{l}{[\mathrm{M}-\mathrm{H}]^{-}} \\
(m / z)\end{array}$ & $\operatorname{MS}^{2}(m / z)$ & Tentative identification & $\begin{array}{l}\text { Green leaves(mg/g } \\
\text { extract) }\end{array}$ & $\begin{array}{l}\text { Yellow leaves (mg/g } \\
\text { extract) }\end{array}$ & $\begin{array}{l}t \text {-Students test } \\
p \text {-value }\end{array}$ \\
\hline 1 & 4.48 & 324 & 341 & $179(100)$ & Caffeic acid hexoside ${ }^{a}$ & $1.80 \pm 0.08$ & $0.44 \pm 0.01$ & $<0.001$ \\
\hline 2 & 5.14 & 324 & 355 & $191(100), 179(46), 173(7), 161(5), 135(11)$ & 3-O-Caffeoylquinic acid ${ }^{\mathrm{a}}$ & $3.5 \pm 0.4$ & $0.191 \pm 0.005$ & $<0.001$ \\
\hline 3 & 5.92 & 312 & 337 & 191(12),173(6),163(100),155(5),119(6) & $\begin{array}{l}\text { cis 3-p-Coumaroylquinic } \\
\operatorname{acid}^{\mathrm{a}}\end{array}$ & $2.34 \pm 0.08$ & $0.99 \pm 0.01$ & $<0.001$ \\
\hline 4 & 6.34 & 312 & 337 & 191(19),163(100),155(5),119(6) & $\begin{array}{l}\text { trans 3-p-Coumaroylquinic } \\
\text { acid }^{\text {a }}\end{array}$ & $6.9 \pm 0.5$ & $2.87 \pm 0.09$ & $<0.001$ \\
\hline 5 & 8.46 & 310 & 339 & $159(100), 115(52)$ & $\begin{array}{l}\text { Dihydroxytetralone } \\
\text { hexoside }^{\mathrm{b}, \mathrm{c}}\end{array}$ & $\mathrm{nq}$ & $\mathrm{nq}$ & - \\
\hline 6 & 9.28 & 320 & 355 & 193(100),175(20) & Ferulic acid hexoside $^{\mathrm{d}}$ & $0.73 \pm 0.06$ & $0.46 \pm 0.01$ & $<0.001$ \\
\hline 7 & 9.85 & 312 & 325 & $163(100)$ & $p$-Coumaric acid hexoside ${ }^{a}$ & $1.43 \pm 0.03$ & $0.91 \pm 0.03$ & $<0.001$ \\
\hline 8 & 15.3 & 350 & 479 & $317(100)$ & Myricetin-3-O-glucoside ${ }^{\mathrm{d}, \mathrm{f}}$ & $0.97 \pm 0.05$ & $0.87 \pm 0.01$ & 0.010 \\
\hline 9 & 17.87 & 350 & 463 & $317(100)$ & Myricetin-O-rhamnoside ${ }^{f}$ & $0.78 \pm 0.01$ & $0.83 \pm 0.03$ & 0.038 \\
\hline 10 & 18.73 & 353 & 463 & $301(100)$ & Quercetin-3-O-glucoside $\mathrm{d}^{\mathrm{d}, \mathrm{f}}$ & $2.79 \pm 0.02$ & $3.64 \pm 0.01$ & $<0.001$ \\
\hline 11 & 19.2 & 353 & 463 & $301(100)$ & Quercetin- $O$-hexoside ${ }^{\mathrm{f}}$ & $2.28 \pm 0.2$ & $2.75 \pm 0.03$ & 0.005 \\
\hline 12 & 20.75 & 350 & 433 & $301(100)$ & Quercetin- $O$-pentoside ${ }^{\mathrm{f}}$ & $0.67 \pm 0.02$ & $0.857 \pm 0.005$ & $<0.001$ \\
\hline 13 & 21.47 & 347 & 447 & $285(100)$ & $\begin{array}{l}\text { Kaempferol-3-O- } \\
\text { glucoside }^{\mathrm{d}}\end{array}$ & $1.12 \pm 0.01$ & $1.27 \pm 0.02$ & $<0.001$ \\
\hline 14 & 21.8 & 351 & 433 & $301(100)$ & Quercetin-O-pentoside ${ }^{\mathrm{f}}$ & $1.43 \pm 0.02$ & $3.21 \pm 0.03$ & $<0.001$ \\
\hline 15 & 22.78 & 350 & 447 & $301(100)$ & Quercetin-O-rhamnoside ${ }^{\mathrm{f}}$ & $1.6 \pm 0.1$ & $2.13 \pm 0.05$ & 0.001 \\
\hline 16 & 24.62 & 348 & 417 & $285(100)$ & Kaempferol-O-pentoside $^{f}$ & $0.721 \pm 0.002$ & $1.03 \pm 0.04$ & $<0.001$ \\
\hline \multirow[t]{4}{*}{17} & 28.86 & 340 & 489 & $447(33), 301(100)$ & $\begin{array}{l}\text { Acetylquercetin } O- \\
\text { rhamnoside }^{\mathrm{d}}\end{array}$ & $0.627 \pm 0.005$ & $0.81 \pm 0.01$ & $<0.001$ \\
\hline & & & & & Total phenolic acids & $16.7 \pm 0.2$ & $5.9 \pm 0.1$ & $<0.001$ \\
\hline & & & & & Total flavonoids & $13.0 \pm 0.2$ & $17.4 \pm 0.2$ & $<0.001$ \\
\hline & & & & & Total phenolic compounds & $29.70 \pm 0.03$ & $23.26 \pm 0.06$ & $<0.001$ \\
\hline
\end{tabular}

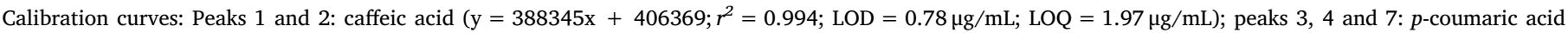

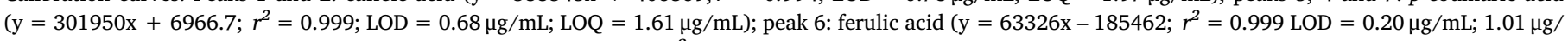
$\mathrm{mL}$ ); peaks 8 to 17: quercetin 3-O-glucoside ( $\mathrm{y}=34843 \mathrm{x}-160173 ; r^{2}=0.9998 ; \mathrm{LOD}=0.21 \mu \mathrm{g} / \mathrm{mL} ; \mathrm{LOQ}=0.71 \mu \mathrm{g} / \mathrm{mL}$ ).

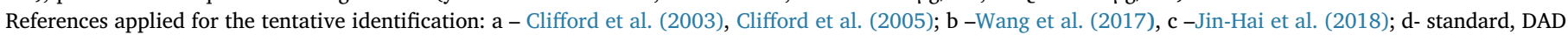
and MS fragmentation pattern; f - Santos et al. (2013).

\section{Results and discussion}

\subsection{Composition in phenolic compounds}

The phenolic composition of the extracts of $J$. regia leaves was assessed for samples in two phenological stages (green and yellow samples, collected in May and November, respectively). The identified molecules and their quantification are presented in Table 1. In this context, phenolic compounds were tentatively identified according to their retention time $(R t)$, maximum absorbance wavelength $\left(\lambda_{\max }\right)$, pseudomolecular ion ([M-H]-), and respective fragmentation pattern $\left(\mathrm{MS}^{2}\right)$. For both samples, it was possible to identify seventeen phenolic compounds: six phenolic acids ( $p$-hydroxycinnamic acid derivatives), ten flavonoids (flavonols) and one tetralone derivative (Fig. 1).

Regarding the six phenolic acids identified in $J$. regia, peak 1 $([\mathrm{M}-\mathrm{H}]-$ at $m / z 341), 6([\mathrm{M}-\mathrm{H}]-$ at $m / z 355)$, and $7([\mathrm{M}-\mathrm{H}]-$ at $m / z$ 325 ) were tentatively identified as caffeic, ferulic, and $p$-coumaric acid hexosides, based on the signal $\mathrm{MS}^{2}$ fragment at $\mathrm{m} / \mathrm{z} 179$ [caffeic acid $\mathrm{H}$ ]-, 193 [ferulic acid - H]-, and 163 [p-coumaric acid - H]-, respectively, revealing the loss of a hexosyl moiety $(-162 \mathrm{u})$. The first two compounds were previously identified byGawlik-Dziki et al. (2014), however, to the best of our knowledge, ferulic acid hexoside has not been previously identified in $J$. regia leaves, hence the free forms of these phenolic acids have also been previously identified (Wichtl and Anton, 1999). Peak $2([\mathrm{M}-\mathrm{H}]-$ at $m / z 353)$ and peaks 3 and 4 $([\mathrm{M}-\mathrm{H}]-$ at $m / z 337)$ were assigned as trans 3 -O-caffeoylquinic acid and cis and trans 3-p-coumaroylquinic acid, respectively. These assumptions were taken into account, due to the hierarchical fragmentation pattern described by Clifford et al. (2003), but also by using literature data described by other authors, that identified these compounds in J. regia leaves (Amaral et al., 2004; Santos et al., 2013; Wichtl and Anton, 1999).

Peak $5([\mathrm{M}-\mathrm{H}]-$ at $m / z$ 353) belongs to a different group of phenolic molecules, the tetralone derivatives. This type of molecules was already reported in Juglans species. The fragmentation yielded the ion at $m / z 159\left([\mathrm{M}-\mathrm{H}]--\mathrm{H}_{2} \mathrm{O}-180\right.$, loss of a hexosyl unit and a neutral loss of water) corresponding to the dihydroxytetralone. This molecule frequently occurs in branches, fruit and pericarps/husks of $J$. mandshurica samples (Bi et al., 2016; Gawlik-Dziki et al., 2014; Jin-Hai et al., 2018; Liu et al., 2004; Wang et al., 2017; Zhou et al., 2015) and $J$. sigillata pericarps (Liu et al., 2010). To the best of our knowledge, it is the first time that the presence of dihydroxytetralone hexoside is reported as a phenolic constituent in $J$. regia leaves. Thus, a similar fragmentation pattern $([\mathrm{M}-\mathrm{H}]-$ at $m / z 339$, with a fragment at 159 , UV-vis maximum absorption, $258,313 \mathrm{~nm}$ ) was previously found by Gawlik-Dziki et al. (2014) in J. regia leaves and pericarps. Nevertheless, the authors stated the molecule as an unknown phenolic compound (Gawlik-Dziki et al., 2014).

The last group of molecules were identified as flavonol glycoside derivatives, such as myricetin, quercetin and kaempferol derivatives. Compounds 8 (myricetin-3-O-glucoside), 10 (quercetin-3-O-glucoside), and 13 (kaempferol-3-O-glucoside) were positively identified by comparison with the corresponding commercial standards. The remaining compounds (peaks 9, 11, 12, and 14-17) were identified as quercetin $\left(\lambda_{\max }=350 \mathrm{~nm} ; \mathrm{MS}^{2}\right.$ fragment at $\mathrm{m} / \mathrm{z}$ 301), kaempferol $\left(\lambda_{\max }=348 \mathrm{~nm} ; \mathrm{MS}^{2}\right.$ fragment at $\left.\mathrm{m} / \mathrm{z} 285\right)$, and myricetin $\left(\lambda_{\max }=350 \mathrm{~nm}, \mathrm{MS}^{2}\right.$ fragment at $\left.m / z 317\right)$, showing a $\mathrm{MS}^{2}$ fragmentation pattern with different losses of hexosyl $(-162 \mathrm{u})$, pentosyl $(-132 \mathrm{u})$, and rhamnosyl $(-146 \mathrm{u})$ residues, being assigned as myricetin-O-rhamnoside (peak 9), quercetin-O-hexoside (peak 11), quercetin- $O$-pentoside (peaks 12 and 14), quercetin- $O$-rhamnoside (peak 15 ), and kaempferol-O-pentoside (peak 16). The majority of the identified compounds have been previously identified by Santos et al. (2013). Finally, peak 17 ([M-H]- at $m / z$ 489) presented $42 \mathrm{u}$ (acetyl moiety) higher then compound 15 (quercetin-O-rhamnoside), being therefore tentatively identified as acetylquercetin- $O$-rhamnoside. In 

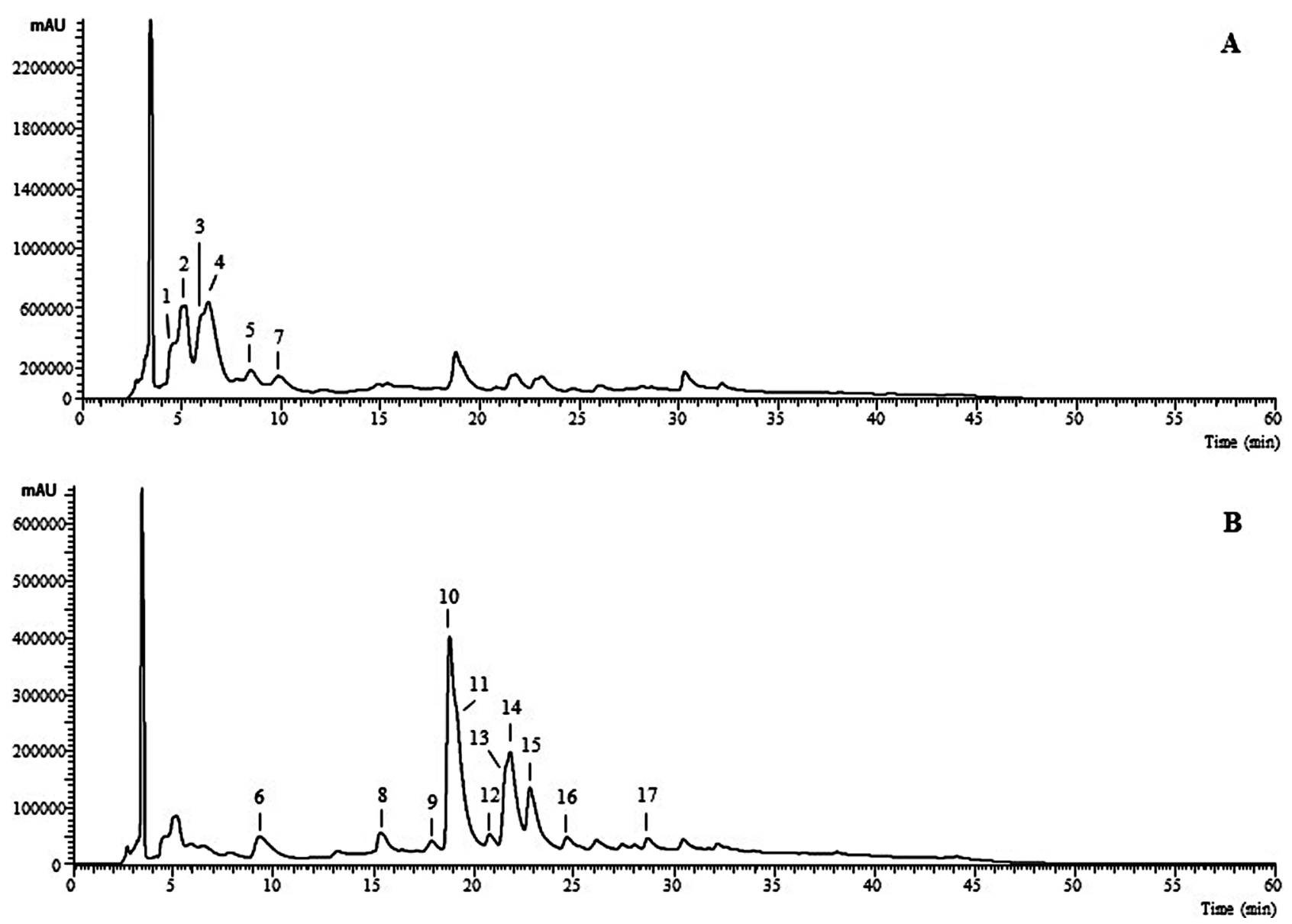

Fig. 1. HPLC phenolic profile of $J$. regia L. leaves. Graphical representation of walnut green sample, recorded at $280 \mathrm{~nm}$ (A) and $370 \mathrm{~nm}$ (B). The peaks identification and quantification are presented in Table 1.

fact, the occurrence of acetyl-quercetin derivatives (and kaempferol as well) in $J$. regia leaves has been also previously described by GawlikDziki et al. (2014).

Regarding the general profile of the samples (Table 1), green leaves were mostly composed by phenolic acids (green samples: $16.7 \pm 0.2 \mathrm{mg} / \mathrm{g}$ extract; yellow samples: $5.9 \pm 0.1 \mathrm{mg} / \mathrm{g}$ extract), while the yellow ones by flavonoids (green samples: $13.0 \pm 0.2 \mathrm{mg} / \mathrm{g}$ extract; yellow samples: $17.4 \pm 0.2 \mathrm{mg} / \mathrm{g}$ extract). Overall, the green leaves of $J$. regia showed a significant higher amount of total phenolic compounds $(29.70 \pm 0.03 \mathrm{mg} / \mathrm{g}$ extract) in comparison to the yellow samples $(23.26 \pm 0.06 \mathrm{mg} / \mathrm{g}$ extract). As previous referred, phenolic acids found in walnut leaves were essentially hydroxycinnamic acids derivatives, being the trans 3-p-coumaroylquinic acid the most abundant phenolic acid for both samples $(6.9 \pm 0.5$ and $2.87 \pm 0.09 \mathrm{mg} / \mathrm{g}$ extract, for green and yellow leaves, respectively). The presence of hydroxycinnamic acid derivatives in $J$. regia leaves is common, regardless of the cultivar or their maturity stage, raising the importance of walnut leaves as a source of this type of bioactive compounds (Amaral et al., 2004; Gawlik-Dziki et al., 2014; Pereira et al., 2007; Pitschmann et al., 2014; Santos et al., 2013; Vieira et al., 2018, 2017; Wojdylo et al., 2007). Regarding the relative abundancy of 3-p-coumaroylquinic acid isomers as the main phenolic acids in walnut leaves samples, that is not frequent; in fact, caffeoylquinic acids have been found as the main phenolic acids. In this context, 3-O-caffeoylquinic acid was reported as the most abundant phenolic acid in several studies (Amaral et al., 2004; Pereira et al., 2007; Santos et al., 2013; Vieira et al., 2017, 2018), while 5-O-caffeoylquinic acid was found in higher concentrations in Chinese samples (Zhao et al., 2014). On the other hand, ellagic acid was the main phenolic acid for Romanian samples
(Pedro cultivar: $1.345 \mathrm{mg} / \mathrm{g}$ of plant $\mathrm{dw}$ ), and caffeic acid for Polish samples (1.48 mg/g of plant dw) (Wojdylo et al., 2007). Despite the atypical relative abundancy of 3-p-coumaroylquinic acid isomers, it is relevant to mention that this compound frequently occurs in walnut leaves (Gawlik-Dziki et al., 2014; Pitschmann et al., 2014). Regarding the amounts found in Portuguese samples, Amaral et al. (2004) reported concentrations about 0.38 to $2.59 \mathrm{mg} / \mathrm{g}$ of plant dw and Pereira et al. (2007) from 4.69 to $5.99 \mathrm{mg} / \mathrm{g}$ of plant dw, depending on the $J$. regia cultivar, while Santos et al. (2013) obtained from 0.92 to $1.2 \mathrm{mg} / \mathrm{g}$ of plant dw. Finally, Zhao et al. (2014) quantified lower values, reaching $0.00672 \mathrm{mg} / \mathrm{g}$ of plant $\mathrm{dw}$ in Chinese walnut leaves.

In general, the amount of the individual flavonoids in $J$. regia leaves was significantly higher for the yellow samples. Quercetin-3-O-glucoside was the most abundant flavonoid for both samples, with yields of $3.64 \pm 0.01$ and $2.79 \pm 0.02 \mathrm{mg} / \mathrm{g}$ of extract in the yellow and green leaves extracts, respectively. Quercetin-O-pentoside (peak 14) was the second main flavonoid in $J$. regia yellow leaves $(3.21 \pm 0.03 \mathrm{mg} / \mathrm{g}$ extract) and the third for the green samples $(1.43 \pm 0.02 \mathrm{mg} / \mathrm{g}$ extract). This tendency was also found by other authors (Santos et al., 2013; Vieira et al., 2017, 2018). In this regard, Santos et al. (2013) found quercetin-3-O-glucoside concentrations around 2.37 to $2.56 \mathrm{mg} /$ $\mathrm{g}$ of plant $\mathrm{dw}$, and, 0.38 to $5.04 \mathrm{mg} / \mathrm{g}$ of plant dw for quercetin- $O$ pentoside for the methanolic extract and decoction, respectively. Higher amounts were found in Spanish hydroethanolic extracts by Vieira et al. (2017), achieving 13.8 to $14.2 \mathrm{mg} / \mathrm{g}$ of plant $\mathrm{dw}$ for quercetin-3-O-glucoside and 11.7 to $14.0 \mathrm{mg} / \mathrm{g}$ of plant $\mathrm{dw}$, depending on the extraction methodology. Later, the authors increased the extraction yields, reaching 16.0 and $14.8 \mathrm{mg} / \mathrm{g}$ of plant $\mathrm{dw}$ for each quercetin derivative by applying choline chloride based-deep eutectic 
Table 2

Antioxidant, anti-inflammatory, and cytotoxic activities of $J$. regia leaves extracts and positive controls (mean $\pm \mathrm{SD}$ ).

\begin{tabular}{|c|c|c|c|}
\hline & \multicolumn{2}{|l|}{ J. regia } & \multirow{2}{*}{$\begin{array}{l}t \text {-Students test } p \text { - } \\
\text { value }\end{array}$} \\
\hline & Green leaves & Yellow leaves & \\
\hline \multicolumn{4}{|c|}{ Antioxidant activity (IC $C_{50}$ values $\mu \mathrm{g} / \mathrm{mL}$ ) } \\
\hline OxHLIA, $\Delta t=60 \mathrm{~min}$ & $32 \pm 2$ & $51 \pm 2$ & $<0.001$ \\
\hline TBARS formation inhibition & $26.8 \pm 0.2$ & $48.5 \pm 0.5$ & $<0.001$ \\
\hline \multicolumn{4}{|c|}{ Anti-inflammatory activity $\left(E C_{50}\right.$ values $\left.\mu \mathrm{g} / \mathrm{mL}\right)$} \\
\hline $\begin{array}{l}\text { Nitric oxide (NO) production } \\
\text { Cytotoxicity }\left(G_{50} \mu \mathrm{g} / \mathrm{mL}\right) \\
\text { Tumor cell lines }\end{array}$ & $319 \pm 13$ & $>400$ & - \\
\hline MCF-7 (breast carcinoma) & $268 \pm 12$ & $305 \pm 5$ & 0.143 \\
\hline $\begin{array}{l}\text { NCI-H460 (non-small lung } \\
\text { carcinoma) }\end{array}$ & $288 \pm 5$ & $328 \pm 5$ & $<0.001$ \\
\hline HeLa (cervical carcinoma) & $280 \pm 8$ & $312 \pm 2$ & 0.002 \\
\hline $\begin{array}{l}\text { HepG2 (hepatocelular } \\
\text { carcinoma) }\end{array}$ & $252 \pm 10$ & $260 \pm 5$ & 0.001 \\
\hline \multicolumn{4}{|l|}{ Non-tumor cells } \\
\hline $\begin{array}{l}\text { PLP2 (porcine liver primary } \\
\text { culture) }\end{array}$ & $>400$ & $>400$ & - \\
\hline
\end{tabular}

$\mathrm{IC}_{50}$ : extract concentration corresponding to a $50 \%$ of antioxidant activity.

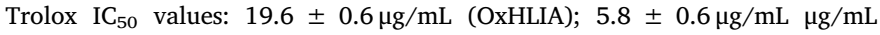
(TBARS inhibition). $\mathrm{GI}_{50}$ values correspond to the sample concentration responsible for $50 \%$ inhibition of growth in a cell culture. $\mathrm{GI}_{50}$ values for Ellipticine (positive control): MCF-7: $1.21 \pm 0.02 \mu \mathrm{g} / \mathrm{mL} ; \quad$ NCI-H460: $0.91 \pm 0.11 \mu \mathrm{g} / \mathrm{mL}$; HeLa: $1.03 \pm 0.09 \mu \mathrm{g} / \mathrm{mL}$; HepG2: $1.1 \pm 0.09 \mu \mathrm{g} / \mathrm{mL}$; PLP2: $2.29 \pm 0.18 \mu \mathrm{g} / \mathrm{mL}$. $\mathrm{EC}_{50}$ values correspond to the sample concentration responsible for $50 \%$ inhibition of NO production. $\mathrm{EC}_{50}$ values for dexamethasone (positive control): $16 \pm 1 \mu \mathrm{g} / \mathrm{mL}$.

solvents. Moreover, quercetin-3-O-galactoside was reported to be the main flavonoid in Portuguese samples, and Amaral et al. (2004) obtained concentrations from 5.15 to $14.90 \mathrm{mg} / \mathrm{g}$ of plant $\mathrm{dw}$, while Pereira et al. (2007) found 15.72 to $21.68 \mathrm{mg} / \mathrm{g}$ of plant dw, depending on the $J$. regia cultivar. The abundancy in flavonols, specially quercetin derivatives, is in good agreement with literature data (Amaral et al., 2004; Cosmulescu et al., 2014; Pereira et al., 2007; Pitschmann et al., 2014; Santos et al., 2013; Vieira et al., 2018, 2017; Zhao et al., 2014). In addition, some walnut leaves also revealed the presence of other flavonoids, such as taxifolin (flavanonol), epicatechin, laricitrin, and procyanidin derivatives (Santos et al., 2013; Zhao et al., 2014).

\subsection{Bioactivity of the hydroethanolic extracts}

The antioxidant potential for the two phenological stages of the $J$. regia leaves was assessed by two in vitro approaches: the inhibition of the lipid peroxidation by the TBARS assay and the anti-haemolytic activity through the OxHLIA assay. The obtained results are presented in Table 2.

The kinetic behavior of the OxHLIA was similar to the previous reported by Lockowandt et al. (2019). The heamolysis profile of the assay using the green leaves extract is depicted in Fig. 2, representing the dose-dependent effect to maintain the erythrocyte integrity. As the graphical representation suggests, the heamolysis can be delayed by increasing the extract concentration.

The green leaves extract showed the highest antioxidant potential for both TBARS and OxHLIA assays, with lower $\mathrm{IC}_{50}$ values than the yellow leaves extract. Regarding the OxHLIA assay, the protection of a half of the erythrocyte population from the heamolysis was achieved by using $32 \pm 2$ and $51 \pm 2 \mu \mathrm{g} / \mathrm{mL}$ concentrations, for green and yellow leaves extracts, respectively. The same tendency was observed for the TBARS assay, with slightly lower IC $_{50}$ values: $26.8 \pm 0.2$ and $48.5 \pm 0.5 \mu \mathrm{g} / \mathrm{mL}$, for green and yellow samples extracts, respectively. The results of the TBARS assay for the green leaves extract is in good agreement with the previous report of $J$. regia leaves methanolic extract by Santos et al. (2013), presenting a IC 50 of $20.36 \pm 0.82 \mu \mathrm{g} / \mathrm{mL}$. Moreover, the antioxidant potential of the walnut leaf essential oil was also evaluated, reaching $50 \%$ of TBARS inhibition formation with about $60 \mu \mathrm{g} / \mathrm{mL}$ (Rather et al., 2012).

The anti-haemolytic activity of walnut leaves was also evaluated by Carvalho et al. (2010b), achieving IC $_{50}$ values around $60 \mu \mathrm{g} / \mathrm{mL}$ after $3 \mathrm{~h}$ of reaction $(\Delta \mathrm{t} \approx 60 \mathrm{~min})$. Regarding the $\mathrm{IC}_{50}$ values for the positive control (Trolox), they were lower than the ones obtained using the extracts $(19.6 \pm 0.6$ and $5.8 \pm 0.6 \mu \mathrm{g} / \mathrm{mL}$, for OxHLIA and TBARS assays, respectively). That is, Trolox shows higher anti-haemolytic and anti-peroxidation activities than the natural extracts. However, Trolox is a pure antioxidant molecule while the extracts are composed by several compounds with different bioactive actions. The extracts showed a lower $\mathrm{IC}_{50}$ value for the TBARS assay compared with OxHLIA, being closer to the positive control in the latter case. In fact, the $\mathrm{IC}_{50}$ values of the extracts are 1.6-2.6 times higher than Trolox ([sample]/ [Trolox]) in the OxHLIA assay, compared with the 4.2-8.4 times difference found for the TBARS assay.

The green leaves extract was the only sample showing inhibition of the NO production up to the maximum concentrations tested $400 \mu \mathrm{g}$ / $\mathrm{mL}$ (Table 2). The concentration with the ability to inhibit $50 \%$ of the nitric oxide production by the macrophages was found to be $319 \pm 3 \mu \mathrm{g} / \mathrm{mL}$. To the best of our knowledge, it is the first time that the anti-inflammatory activity evaluation though an immune cells approach is made for this plant material. Nevertheless, the NO inhibition production by walnut leaves extracts was previous studied as antioxidant indicators. In this context, $\mathrm{IC}_{50}$ values of $1.95 \pm 0.29 \mu \mathrm{g} / \mathrm{mL}$ were obtained by measuring the NO generated by the NOC-5 (nitric oxide amine-complex donor) decomposition. Moreover, Orhan et al. (2011) quantified the radical scavenging activity of a series of extracts obtained from different solvents (dichloromethane, ethyl acetate, acetone, methanol and water), and the leaf water extract at $2000 \mu \mathrm{g} / \mathrm{mL}$ was able to inhibit about $24 \%$ of the NO production. On the other hand, some authors used mice models to perform the anti-inflammatory evaluations. The carrageenan-induced paw edema in mice assay was adopted by Erdemoglu et al. (2003), and showed potent anti-inflammatory activity for the ethanolic extract, achieving $67.9 \%$ of inhibitory ratios, without any gastric lesions. Later, Hosseinzadeh et al. (2011) used the xylene-induced ear edema and the chronic inflammation (cotton-plate) test for the same purpose, achieving effective doses in lower concentrations for the ethanolic extract of $J$. regia leaves than the aqueous one. Overall, the data presented in this work demonstrate the anti-inflammatory potential of ethanolic-based extracts of walnut green leaves using a different method.

The results concerning the cytotoxic potential of the samples are also presented in Table 2. Regarding the results for the tumor cell cultures, the green leaves of $J$. regia showed a significant higher antiproliferative potential against to all the cell lines assessed. The most susceptible cell culture was the HepG2 (hepatocellular carcinoma) one, being a half of the cell proliferation inhibited by concentrations about $252 \pm 10$ to $260 \pm 5 \mu \mathrm{g} / \mathrm{mL}$ (green and yellow samples, respectively), while the NCI-H460 (non-small lung carcinoma) cells were the less vulnerable ones $\left(\mathrm{GI}_{50}=288 \pm 5\right.$ and $328 \pm 5 \mu \mathrm{g} / \mathrm{mL}$, respectively, for the green and yellow samples). Interestingly, a sample previously studied from the same origin, did not present activity against these nonsmall lung cancer cell line $\left(\mathrm{GI}_{50}>400 \mu \mathrm{g} / \mathrm{mL}\right.$ ) (Santos et al., 2013). This fact is easily justified by environmental changes, which contribute for phytochemical differences and then, slight variations in terms of bioactivities. Even so, these results are very close to the previously reported by the authors for methanolic and decoction extracts (Santos et al., 2013). The proliferative inhibition of human renal (A-498 and 769-P) and colon (Caco-2) tumor cell lines was prior evaluated by Carvalho et al. (2010b), achieving the walnut leaves methanolic extracts $\mathrm{GI}_{50}$ of 226,352 and $229 \mu \mathrm{g} / \mathrm{mL}$, respectively. Furthermore, the extracts studied by Santos et al. (2013) also presented anti-proliferative action against the human colon carcinoma (HCT-15) with $\mathrm{GI}_{50}$ of 215 to 


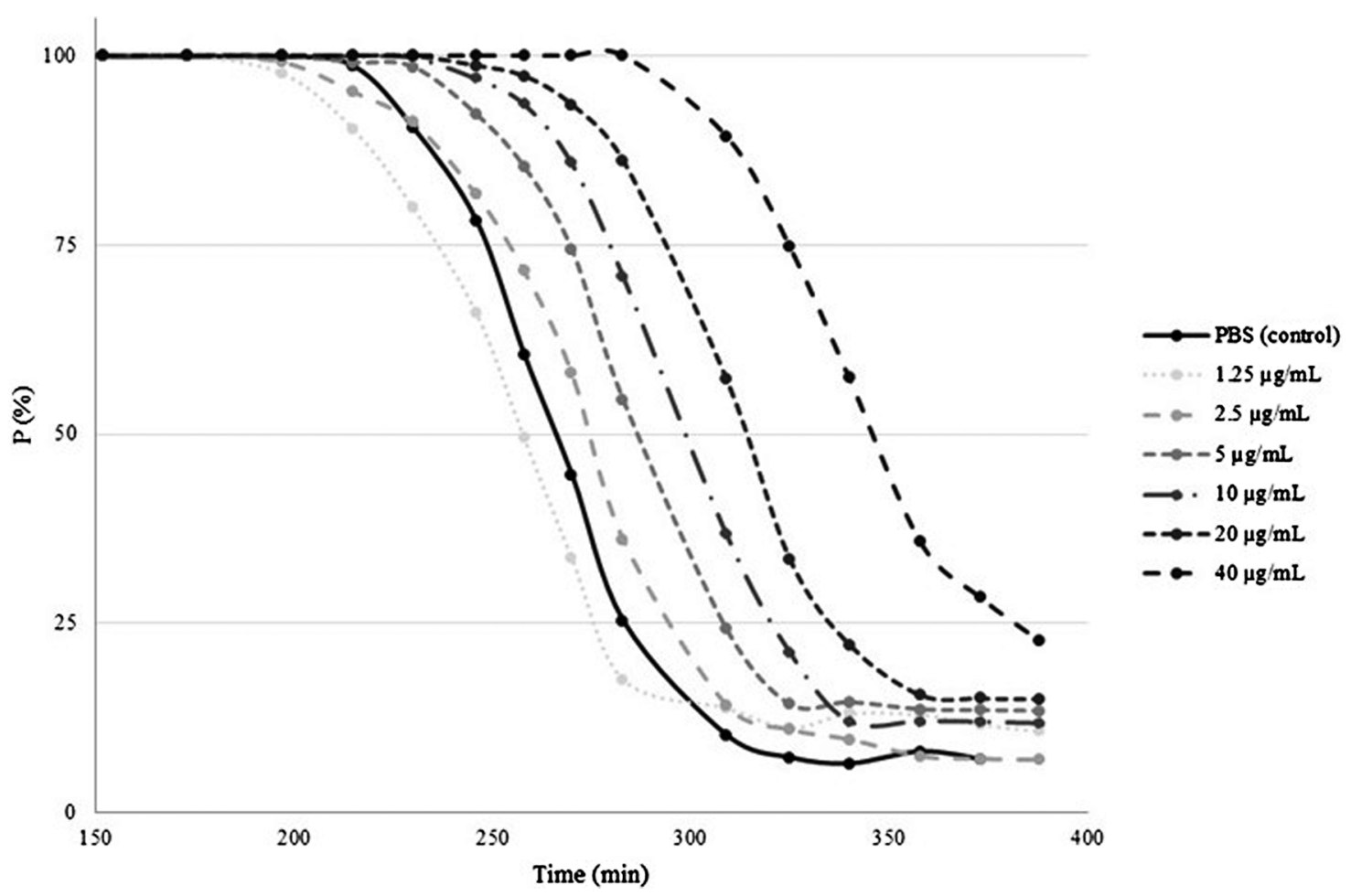

Fig. 2. Kinetic profile of the action of $J$. regia green leaves extract during the erythrocyte heamolysis (OxHLIA assay).

$258 \mu \mathrm{g} / \mathrm{mL}$ (methanol extract and decoction, correspondingly).

Finally, the tested extracts did not reveal cytotoxicity for the primary liver porcine cells (PLP2) up to $400 \mu \mathrm{g} / \mathrm{mL}$. These results are according to the previous observations of Santos et al. (2013), for both methanolic and decoction extracts. Besides the evidences about absence of hepatotoxicity, a study performed by Eidi et al. (2013) showed a positive effect over the liver in an in vivo model. The authors observed a hepatoprotective effect in rats against the carbon tetrachloride $\left(\mathrm{CCl}_{4}\right)$ induced oxidation damage in rats by an aqueous-ethanolic extract.

The walnut leaves hydroethanolic extracts were also studied regarding their antimicrobial properties. To this end, five Gram-negative (E. coli, K. pneumoniae, M. morganii, P. mirabilis, and $P$. aeruginosa) and three Gram-positive (E. fecalis, L monocytogenes, and MRSA) bacteria were selected. Data regarding the antibacterial activity of the extracts are presented in Table 3. The obtained results do not vary between samples, being the antibacterial potential of walnut leaves independent of the maturity stage. Furthermore, those results suggest a selective action against the Gram-positive strains. In fact, the achieved MIC values for the Gram-negative bacteria are about $20 \mathrm{mg} / \mathrm{mL}$ (E. coli and $K$. pneumoniae) or higher (M. morganii, P. mirabilis and P. aeruginosa), while the results for the Gram-positive ones are considerably lower $(\geq$ $5 \mathrm{mg} / \mathrm{mL}$ ). The lowest MIC value (highest antibacterial activity) was observed in E. faecalis and L. monocytogenes ( $\mathrm{MIC}=2.5 \mathrm{mg} / \mathrm{mL}$ ). Comparatively, the methicillin-resistant $S$. aureus (MRSA) was inhibited with a higher concentration ( $\mathrm{MIC}=5 \mathrm{mg} / \mathrm{mL}$ ). These findings allied to the fact that none of the extracts showed MBC up to $20 \mathrm{mg} / \mathrm{mL}$, make $J$. regia leaves extracts good candidates for applications aiming to establish the balance of natural flora caused by Gram-positive bacteria proliferation. In this regard, the provided data of the present work, endorse the proposal of Qa'dan et al. (2005) for the use of J. regia leaves extracts for acne treatment.

In a previous study (also using bacteria from clinical isolates), Pereira et al. (2007) also reported the preferable Gram-positive susceptibility of $J$. regia leaves aqueous extracts from different Portuguese cultivars. The authors determined the MIC according to the agar streak dilution method based on radial diffusion, reporting concentrations about 0.1 to $1 \mathrm{mg} / \mathrm{mL}$ able to inhibit the $S$. aureus growth. The extracts were active against other Gram-positive bacteria $(B$. cereus and $B$.

Table 3

Antimicrobial activity (MIC and MBC mean values) of $J$. regia leaves extracts and positive controls.

\begin{tabular}{|c|c|c|c|c|c|c|c|c|c|c|}
\hline & \multicolumn{2}{|c|}{ Green leaves } & \multicolumn{2}{|c|}{ Yellow leaves } & \multicolumn{2}{|c|}{ Ampicillin $(20 \mathrm{mg} / \mathrm{mL})$} & \multicolumn{2}{|c|}{ Imipenem (1 mg/mL) } & \multicolumn{2}{|c|}{ Vancomycin $(1 \mathrm{mg} / \mathrm{mL})$} \\
\hline & MIC & MBC & MIC & MBC & MIC & MBC & MIC & $\mathrm{MBC}$ & MIC & MBC \\
\hline \multicolumn{11}{|l|}{ Gram-negative bacteria } \\
\hline Escherichia coli & 20 & $>20$ & 20 & $>20$ & $<0.15$ & $<0.15$ & $<0.0078$ & $<0.0078$ & nt & nt \\
\hline Klebsiella pneumoniae & 20 & $>20$ & 20 & $>20$ & 10 & 20 & $<0.0078$ & $<0.0078$ & nt & $\mathrm{nt}$ \\
\hline Morganella morganii & $>20$ & $>20$ & $>20$ & $>20$ & 20 & $>20$ & $<0.0078$ & $<0.0078$ & nt & $\mathrm{nt}$ \\
\hline Proteus mirabilis & $>20$ & $>20$ & $>20$ & $>20$ & $<0.15$ & $<0.15$ & $<0.0078$ & $<0.0078$ & nt & nt \\
\hline Pseudomonas aeruginosa & $>20$ & $>20$ & $>20$ & $>20$ & $>20$ & $>20$ & 0.5 & 1 & nt & $\mathrm{nt}$ \\
\hline \multicolumn{11}{|l|}{ Gram-positive bacteria } \\
\hline Enterococcus faecalis & 2.5 & $>20$ & 2.5 & $>20$ & $<0.15$ & $<0.15$ & nt & nt & $<0.0078$ & $<0.0078$ \\
\hline Listeria monocytogenes & 2.5 & $>20$ & 2.5 & $>20$ & $<0.15$ & $<0.15$ & nt & $\mathrm{nt}$ & nt & nt \\
\hline MRSA $^{*}$ & 5 & $>20$ & 5 & $>20$ & $<0.15$ & $<0.15$ & $\mathrm{nt}$ & nt & $<0.0078$ & $<0.0078$ \\
\hline
\end{tabular}

MRSA- Methicillin Resistant Staphylococcus aureus; MIC: minimal inhibitory concentration; MBC: minimal bactericidal concentration; nt: not tested. 
subtilis), but not for the studied Gram-negative ones ( $P$. aeruginosa, $E$. coli and $K$. pneumonia). However, the study guided by Dolatabadi et al. (2018) using Iranian walnut leaves (aqueous and methanolic) extracts against clinical isolates of $P$. aeruginosa, revealed positive results. The authors used the microdilution method, determining the MIC and MBC of the samples by ELISA, achieving inhibitions with 4 and $8 \mathrm{mg} / \mathrm{mL}$ and bactericidal effect using 8 and $16 \mathrm{mg} / \mathrm{mL}$ (aqueous and methanolic extract, respectively). Iranian samples were also tested against other Gram-positive strains by Sharafati-Chaleshtori et al. (2011). The authors tested hydroethanolic extracts against face oral problematic bacteria ( $S$. mutans, $S$. salivarius, $S$. sanguinis and $A$. viscosus), obtaining MIC values from 15.6 to $187.5 \mathrm{mg} / \mathrm{mL}$ and the MBC ranged from 31.25 to $250 \mathrm{mg} / \mathrm{mL}$. The problematic bacteria $M$. turbeculosis was successfully inhibited by Mexican (walnut leaves) methanolic extract, with MIC values of $125 \mu \mathrm{g} / \mathrm{mL}$. Finally, the bactericidal effect of Indian $J$. regia leaves essential oil was also an object of study by Rather et al. (2012), presenting lower MIC values against Gram-positive bacteria (B. subtilis, $S$. epidermidis and $S$. aureus) than the Gram-negative ones ( $E$. coli, K. pneumonia, P. aeruginosa, $P$. vulgaris, $S$. typhi and $S$. dyssenteriae).

\section{Conclusions}

The Portuguese walnut leaves proved to be a good source of hydroxycinnamic acid derivatives and flavonols, especially trans 3-pcoumaroylquinic acid and quercetin-3-O-glucoside. The former compounds were abundant in green samples, while the later ones were found in higher amounts in the yellow samples. The green leaves extract showed the highest antioxidant activity, being more capable to inhibit the lipid peroxidation as well as the erythrocyte heamolysis. Similarly, in the anti-inflammatory assay, only green samples presented anti-inflammatory potential. It was also verified a cytotoxic effect against tumor cell lines, but not for the non-tumor ones. Furthermore, both extracts were active against Gram-positive bacteria. Overall, this study shows the importance of walnut leaves as a source of bioactive molecules, providing antioxidant, anti-inflammatory, anti-proliferative and antibacterial properties, with potential to be used by different industries.

\section{Acknowledgements}

The authors thank the Foundation for Science and Technology (FCT, Portugal) and FEDER under Programme PT2020 for financial support to CIMO (UID/AGR/00690/2013), L. Barros, R. Calhelha and Carla Pereira contracts and V. Vieira (SFRH/BD/108487/2015) and T. Pires (SFRH/BD/129551/2017) grants. To UID/CTM/50011/2019 (CICECO), financed by national funds through the FCT/MCTES. To POCI-01-0145-FEDER-006984 (LA LSRE-LCM), funded by ERDF, through POCI-COMPETE2020 and FCT. To project AllNat - POCI-010145-FEDER-030463, financed by national funds through the FCT, and by COMPETE and Portugal2020, and to FEDER-Interreg EspañaPortugal programme for financial support through the project 0377_Iberphenol_6_E.

\section{References}

Abdoli, M., Hashem, F.D., Goushegir, A., Shirazi, M.T., Nakhjavani, M., Shojaii, A., Rezvani, S., Mahlooji, K., 2017. Anti-hyperglycemic effect of aqueous extract of Juglans regia L. leaf (walnut leaf) on type 2 diabetic patients: a randomized controlled trial. Adv. Integr. Med. 4, 98-102.

Abreu, R.M.V., Ferreira, I.C.F.R., Calhelha, R.C., Lima, R.T., Vasconcelos, M.H., Adega, F., Chaves, R., Queiroz, M.J.R.P., 2011. Anti-hepatocellular carcinoma activity using human HepG2 cells and hepatotoxicity of 6-substituted methyl 3-aminothieno[3,2-b] pyridine-2- carboxylate derivatives: in vitro evaluation, cell cycle analysis and QSAR studies. Eur. J. Med. Chem. 46, 5800-5806.

Amaral, J.S., Seabra, R.M., Andrade, P.B., Valentão, P., Pereira, J.A., Ferreres, F., 2004. Phenolic profile in the quality control of walnut (Juglans regia L.) leaves. Food Chem. 88, 373-379.

Asgary, S., Parkhideh, S., Solhpour, A., Madani, H., Mahzouni, P., Rahimi, P., 2008. Effect of ethanolic extract of Juglans regia L. on blood sugar in diabetes-induced rats. J.
Med. Food 11, 533-538.

Barreira, J.C.M., Rodrigues, S., Carvalho, A.M., Ferreira, I.C.F.R., 2013. Development of hydrosoluble gels with Crataegus monogyna extracts for topical application: evaluation of antioxidant activity of the final formulations. Ind. Crops Prod. 42, 175-180.

Barros, L., Pereira, E., Calhelha, R.C., Dueñas, M., Carvalho, A.M., Santos-Buelga, C., Ferreira, I.C.F.R., 2013. Bioactivity and chemical characterization in hydrophilic and lipophilic compounds of Chenopodium ambrosioides L. J. Funct. Foods 5, $1732-1740$.

Bessada, S.M.F., Barreira, J.C.M., Barros, L., Ferreira, I.C.F.R., Oliveira, M.B.P.P., 2016. Phenolic profile and antioxidant activity of Coleostephus myconis (L.) Rchb.f.: an underexploited and highly disseminated species. Ind. Crops Prod. 89, 45-51.

Bi, D., Zhao, Y., Jiang, R., Wang, Y., Tian, Y., Chen, X., Bai, S., She, G., 2016. Phytochemistry, bioactivity and potential impact on health of Juglans: the original plant of walnut. Nat. Prod. Commun. 11, 869-880.

Carocho, M., Ferreira, I.C.F.R., 2013. A review on antioxidants, prooxidants and related controversy: natural and synthetic compounds, screening and analysis methodologies and future perspectives. Food Chem. Toxicol. 51, 15-25.

Carvalho, A.M., Morales, R., Morales, Ramón, 2010a. Persistence of wild food and wild medicinal plant knowledge in a northeastern region of Portugal. In: Prado-deSantayana, M., Pieroni, A., Puri, R. (Eds.), Ethnobotany in the New Europe: People, Health and Wild Plant Resources. Berghahn Books, pp. 147-172.

Carvalho, M., Ferreira, P.J., Mendes, V.S., Silva, R., Pereira, J.A., Jerónimo, C., Silva, B.M., 2010b. Human cancer cell antiproliferative and antioxidant activities of Juglans regia L. Food Chem. Toxicol. 48, 441-447.

Clifford, M.N., Johnston, K.L., Knight, S., Kuhnert, N., 2003. Hierarchical scheme for LCMSn identification of chlorogenic acids. J. Agric. Food Chem. 51, 2900-2911.

Clifford, M.N., Knight, S., Kuhnert, N., 2005. Discriminating between the six isomers of dicaffeoylquinic acid by LC-MSn. J. Agric. Food Chem. 53, 3821-3832.

European Commission, 2006. Commission decision of 9 February 2006 amending decision 96/335/EC establishing an inventory and a common nomenclature of ingredients employed in cosmetic products (2006/257/EC). Off. J. Eur. Union 1-528.

Cosmulescu, S., Trandafir, I., Achim, G., Baciu, A., 2011. Juglone content in leaf and green husk of five walnut (Juglans regia L.) cultivars. Not. Bot. Horti Agrobot. ClujNapoca 39, 237-240.

Cosmulescu, S., Trandafir, I., Nour, V., 2014. Seasonal variation of the main individual phenolics and juglone in walnut (Juglans regia) leaves. Pharm. Biol. 52, 575-580.

Dolatabadi, S., Nesari, H., Mahdavi-ourtakand, M., 2018. Microbial pathogenesis evaluating the anti-biofilm and antibacterial effects of Juglans regia L. extracts against clinical isolates of Pseudomonas aeruginosa. Microb. Pathog. 118, 285-289.

Eidi, A., Moghadam, J.Z., Mortazavi, P., Olamafar, S., 2013. Hepatoprotective effects of Juglans regia extract against CCl4-induced oxidative damage in rats. Pharma 51, $558-565$.

Erdemoglu, N., Küpeli, E., Yeşilada, E., 2003. Anti-inflammatory and antinociceptive activity assessment of plants used as remedy in Turkish folk medicine. J. Ethnopharmacol. 89, 123-129.

Evans, B.C., Nelson, C.E., Yu, S.S., Beavers, K.R., Kim, A.J., Li, H., Nelson, H.M., Giorgio, T.D., Duvall, C.L., 2013. Ex vivo red blood cell hemolysis assay for the evaluation of $\mathrm{pH}$-responsive endosomolytic agents for the cytosolic delivery of biomacromolecular drugs. J. Vis. Exp. 73, 1-5.

Forino, M., Stiuso, P., Lama, S., Ciminiello, P., Tenore, G.C., Novellino, E., TaglialatelaScafati, O., 2016. Bioassay-guided identification of the antihyperglycaemic constituents of walnut (Juglans regia) leaves. J. Funct. Foods 26, 731-738.

Gawlik-Dziki, U., Durak, A., Pecio, L., Kowalska, I., 2014. Nutraceutical potential of tinctures from fruits, green husks, and leaves of Juglans regia L. Sci. World J. 1-10.

Gîrzu, M., Carnat, A., Privat, A., Fialip, J., Carnat, A., Lamaison, J., Carnat, A., Privat, A., Fialip, J., Carnat, A., Lamaison, J., 1998. Sedative effect of walnut leaf extract and juglone, an isolated constituent. Pharm. Biol. 36, 280-286.

Hosseini, S., Jamshidi, L., Mehrzadi, S., Mohammad, K., Najmizadeh, A.R., Alimoradi, H., Huseini, H.F., 2014. Effects of Juglans regia L. leaf extract on hyperglycemia and lipid profiles in type two diabetic patients: a randomized double-blind, placebo-controlled clinical trial. J. Ethnopharmacol. 152, 451-456.

Hosseinzadeh, H., Zarei, H., Taghiabadi, E., 2011. Antinociceptive, anti-inflammatory and acute toxicity effects of Juglans regia L. leaves in mice. Iran. Red Crescent Med. J. $13,27-33$

Javidanpour, S., Reza, S., Tabtabaei, F., Siahpoosh, A., Morovati, H., Shahriari, A., 2012 Comparison of the effects of fresh leaf and peel extracts of walnut (Juglans regia L.) on blood glucose and $\beta$-cells of streptozotocin-induced diabetic rats. Vet. Res. Forum 3, 251-255.

Jin-Hai, H., Xiao-Wei, D., Guo-Dong, S., Wen-Ting, D., Wei-Ming, W., 2018. Identification and characterization of major constituents in Juglans mandshurica using ultra performance liquid chromatography coupled with time-of- flight mass spectrometry (UPLC-ESI-Q-TOF/MS). Chin. J. Nat. Med. 16, 525-545.

Kuete, V., Kamga, J., Sandjo, L.P., Ngameni, B., Poumale, H.M.P., Ambassa, P., Ngadjui, B.T., 2011. Antimicrobial activities of the methanol extract and compounds from Artocarpus communis (Moraceae). BMC Complement. Altern. Med. 11, 1-6.

Liu, L., Li, W., Koike, K., Zhang, S., Nikaido, T., 2004. New a-tetralonyl glucosides from the fruit of Juglans mandshurica. Chem. Pharm. Bull. 52, 566-569.

Liu, Q., Zhao, P., Li, X.-C., Jacob, M.R., Yang, C.-R., Zhang, Y.-J., 2010. New $\alpha$-tetralone galloylglucosides from the fresh pericarps of Juglans sigillata. Helv. Chim. Acta 93, 265-271.

Lockowandt, L., Pinela, J., Lobo, C., Pereira, C., Abreu, R.M.V., Calhelha, R.C., José, M., Barros, L., Bredol, M., Ferreira, I.C.F.R., 2019. Chemical features and bioactivities of cornflower (Centaurea cyanus L.) capitula: the blue flowers and the unexplored nonedible part. Ind. Crops Prod. 128, 496-503.

Mohammadi, J., Delaviz, H., Malekzadeh, J.M., Roozbehi, A., 2012. The effect of hydro 
alcoholic extract of Juglans regia leaves in streptozotocin-nicotinamide induced diabetic rats. Pak. J. Pharm. Sci. 25, 407-411.

Mollica, A., Zengin, G., Locatelli, M., Stefanucci, A., Macedonio, G., Bellagamba, G., Onaolapo, O., Onaolapo, A., Azeez, F., Ayileka, A., Novellino, E., 2017. An assessment of the nutraceutical potential of Juglans regia L. leaf powder in diabetic rats Food Chem. Toxicol. 107 (Part), 554-564.

Orhan, I.E., Suntar, I.P., Akkol, E.K., 2011. In vitro neuroprotective effects of the leaf and fruit extracts of Juglans regia L. (walnut) through enzymes linked to Alzheimer's disease and antioxidant activity. Int. J. Food Sci. Nutr. 62, 781-786.

Panth, N., Paudel, K.R., Karki, R., 2016. Phytochemical profile and biological activity of Juglans regia. J. Integr. Med. 14, 359-373.

Pereira, J.A., Oliveira, I., Sousa, A., Valentão, P., Andrade, P.B., Ferreira, I.C.F.R., Ferreres, F., Bento, A., Seabra, R., Estevinho, L., 2007. Walnut (Juglans regia L.) leaves: phenolic compounds, antibacterial activity and antioxidant potential of different cultivars. Food Chem. Toxicol. 45, 2287-2295.

Perusquía, M., Mendoza, S., Bye, R., Linares, E., Mata, R., 1995. Vasoactive effects of aqueous extracts from five Mexican medicinal plants on isolated rat aorta. J. Ethnopharmacol. 46, 63-69.

Pires, T.C.S.P., Dias, M.I., Barros, L., Alves, M.J., Oliveira, M.B.P.P., Santos-Buelga, C., Ferreira, I.C.F.R., 2018. Antioxidant and antimicrobial properties of dried Portuguese apple variety (Malus domestica Borkh. cv Bravo de Esmolfe). Food Chem. 240, 701-706.

Pitschmann, A., Zehl, M., Atanasov, A.G., Dirsch, V.M., Heiss, E., Glasl, S., 2014. Walnut leaf extract inhibits PTP1B and enhances glucose-uptake in vitro. J. Ethnopharmacol. 152, 599-602.

Qa'dan, F., Thewaini, A., Ali, D.A., Afifi, R., Elkhawad, A., Matalka, K.Z., 2005. The antimicrobial activities of Psidium guajava and Juglans regia Leaf extracts to acnedeveloping organisms. Am. J. Chin. Med. 33, 197-204.

Rather, M.A., Dar, B.A., Dar, M.Y., Wani, B.A., Shah, W.A., Bhat, B.A., Ganai, B.A., Bhat, K.A., Anand, R., Qurishi, M.A., 2012. Chemical composition, antioxidant and antibacterial activities of the leaf essential oil of Juglans regia L. and its constituents. Phytomedicine 19, 1185-1190.

Salimi, M., Ardestaniyan, M.H., Mostafapour Kandelous, H., Saeidnia, S., Gohari, A.R., Amanzadeh, A., Sanati, H., Sepahdar, Z., Ghorbani, S., Salimi, M., 2014. Anti-proliferative and apoptotic activities of constituents of chloroform extract of Juglans regia leaves. Cell Prolif. 47, 172-179.

Santos, A., Barros, L., Calhelha, R.C., Dueñas, M., Carvalho, A.M., Santos-Buelga, C., Ferreira, I.C.F.R., 2013. Leaves and decoction of Juglans regia L.: different performances regarding bioactive compounds and in vitro antioxidant and antitumor effects. Ind. Crops Prod. 51, 430-436.

Schwindl, S., Kraus, B., 2017. Phytochemical study of Juglans regia L. leaves. Phytochemistry 144, 58-70.

Sharafati-Chaleshtori, R., Sharafati-Chaleshtori, F., Rafieian, M., 2011. Biological characterization of Iranian walnut (Juglans regia) leaves. Turk. J. Biol. 35, 635-639.

Takebayashi, J., Iwahashi, N., Ishimi, Y., Tai, A., 2012. Development of a simple 96-well plate method for evaluation of antioxidant activity based on the oxidative haemolysis inhibition assay (OxHLIA). Food Chem. 134, 606-610.

Tasneem, S., Liu, B., Li, B., Choudhary, M.I., Wang, W., 2019. Molecular pharmacology of inflammation: medicinal plants as anti-inflammatory agents. Pharmacol. Res. 139, $126-140$.

Teimori, M., Kouhsari, M., Ghafarzadegan, R., Hajiaghaee, R., 2009. Study of hypoglycemic effect of Juglans regia leaves and its mechanism. J. Med. Plants 9, 57-65.

Vieira, V., Prieto, M.A., Barros, L., Coutinho, J.A.P., Ferreira, O., Ferreira, I.C.F.R., 2017. Optimization and comparison of maceration and microwave extraction systems for the production of phenolic compounds from Juglans regia L. for the valorization of walnut leaves. Ind. Crops Prod. 115, 261-271.

Vieira, V., Prieto, M.A., Barros, L., Coutinho, J.A.P., Ferreira, I.C.F.R., Ferreira, O., 2018. Enhanced extraction of phenolic compounds using choline chloride based deep eutectic solvents from Juglans regia L. Ind. Crops Prod. 115, 261-271.

Wang, X., Zhao, M., Su, G., Cai, M., Zhou, C., Huang, J., Lin, L., 2015. The antioxidant activities and the xanthine oxidase inhibition effects of walnut (Juglans regia L.) fruit, stem and leaf. Int. J. Food Sci. Technol. 50, 233-239.

Wang, T.-M., Fu, Y., Yu, W.-J., Chen, C., Di, X., Zhang, H., Zhai, Y.-J., Chu, Z.-Y., Kang, T.G., Chen, H.-B., 2017. Identification of polar constituents in the decoction of Juglans mandshurica and in the medicated egg prepared with the decoction by HPLC-Q-TOF MS2. Molecules 22, 1-16.

Wichtl, M., Anton, R., 1999. Plantes thérapeutiques. Tec.\&Doc., Paris.

Wojdylo, A., Oszmianski, J., Czemerys, R., 2007. Antioxidant activity and phenolic compounds in 32 selected herbs. Food Chem. 105, 940-949.

Zhao, M., Jiang, Z., Liu, T., Li, R., 2014. Flavonoids in Juglans regia L. leaves and evaluation of in vitro antioxidant activity via intracellular and chemical methods. Sci. World J. 2014, 1-6.

Zhou, Y., Yang, B., Jiang, Y., Liu, Z., Liu, Y., Wang, X., Kuang, H., 2015. Studies on cytotoxic activity against HepG-2 cells of naphthoquinones from Green walnut husks of Juglans mandshurica Maxim. Molecules 20, 15572-15588. 